\title{
非線形地価関数モデルによる新線建設の外部効果の定量化
}

Quantification of External Effects associated with a New Railroad through a Non-linear Function of Land Price.

\author{
* 児 玉 文 雄 \\ By Fumio KODAMA \\ 粎鎌田康 \\ Yasushi KAMADA
}

\begin{abstract}
Land price is formulated as a function of the distance from railroad station. The database of land prices for 37 stations in Saitama prefecture is constructed. Two types of non-linear function are selected: exponential (independent town type) and piecewise-linear(bed town type). This assumption concerning the correspondence between function type and town type is proved by statistical tests. The use of non-linear function makes it possible to estimate the upper limit of distance which will be influenced by the existence of the station. This limit turns out to be a function of the distance from the downtown of Tokyo. Thus, the combination of these models makes the quantification of external effects possible. This was applied to Saikyou Line.
\end{abstract}

1. 緒言

大都市圏においては、慢性的な通勤地獄解消のた め，鉄道の整備が急務とされているが，建設投資の 急騰と工事の長期化が鉄道経営を圧迫し，鉄道事業 者の自己財源による新線建設を難しくしている。し かしながら, 新線の開通により, 沿線地域は膨大な 外部効果を得ることから, 外部効果を適正な方法で 推定し,できるだけ内部化することこそ, 不労所得 の再分配に上る経済的公平性の実現と安定財源の確 保への有力な手段となりうる。本研究は, 駅勢圈内 の地価構造を分析し, 都心への時間距離が地価に与 える影響度の定量化を行ないながら, 新線建設がも たらす外部効果の定量化, 及び, 費用便益比を算定

* 工博 埼玉大学教授 大学院政策科学研究科

( $\mathbf{T} 338$ 浦和市下大久保 255 )

** 正会員 学修 日本国有鉄道盛岡工事事務所

( $\mathbf{T} 020$ 盛岡市盛岡駅前通 1 - 41)
するととにより，その内部化施策への道標を与える ためのものである。

通勤鉄道の開通がもたらす外部効果は様々なもの があるが，そのほとんどは地価に反映されるため， 鉄道の有無による地価格差を分析することにより外 部効果の計測が可能である。てのような観点から， 従来, 地価関数に上る地価上昇額算定に関する多く の研究が行われてきたが, 使用された地価関数には 問題点も少なくない。

第一に, データ等の制約により, 地価関数を沿線 全体, 若しくは特定地域で構築しているため, 駅ゃ 駅が属する都市の性格が考慮されていないととであ る。地価の分布も，駅を中心とする街の属性に影響 を受けると考えられ, 各駅勢圈毎に地価関数を求め ろ必要がある。また，従来の分析のほとんどが線形 回帰によって地価関数を構築しており, 線形関数系 の構造（駅から無限遠方で地価収束値が 0 となる） が非現実的である。そこで, 駅から無限遠方におい 
て一定值に収束する非線形関数を地価関数に導入す べきである。更に, 線形関数の構造的制約により, 鉄道開通による地価上昇範囲( 本研究では, 駅の存 在による地価上昇範囲を駅勢圈とする。）をあらか ビめ仮定しており,すべての駅の駅勢圈を同一視し ているため, 駅勢圈を推定する回帰式を構築する必 要がある。本研究では以上の点を考慮して地価関数 の構築を行なうこととした。

2. 非線形地価関数モデル構築の手順

（1）駅勢圏毎のデフレータ作成

地価のデータは「地価公示」，「基準地の標準価 格（1月1日換算）」を用いたが，単年データでは， 駅単位のデータが極めて少なくなるため, 各年のデ ータをプールする必要がある。こてでは, 駅の存在 により，地価に影響があるといわれている，駅から $2 \mathrm{~km}$ 圈の, 昭和 51 年〜 59 年の隔年の宅地データ について, 各駅勢圏毎に(1)式によってダミ一回為を 行なった。

$$
\begin{aligned}
\log (Y) & =a+b * Y+d 3+d 5+d 7 \\
& +d 9
\end{aligned}
$$

$\mathrm{Y}$ ：地価(万円 $/$ 平米)

$\mathrm{X}$ : 駅から道路距離 $(\mathrm{M})$

$\mathrm{d}_{\mathrm{i}}$ : 昭和 $\left(\begin{array}{ll}5 & 0+\mathrm{i}\end{array}\right)$ 年ダ -

(1)式は, 図 1 亿示すとおり, 同一年では指数関 数となり，年毎には，上方にシフトする関数であ る。(1)式によってデフレータが得られるのは, 同一 駅勢圏内の各地点については, 同率で地価が上昇す るという前提にたっている。すなわち, 昭和（５０ $+\mathrm{i})$ 年のデフレータを $\mathrm{r}_{\mathrm{i}}=\mathrm{e} \times \mathrm{p}(\mathrm{d} 9-\mathrm{d} \mathrm{i})$ （ただし $\mathrm{d} 1$ ＝0）とするととによって，毎年の 各駅勢圈毎のデフレータが得られる。そてで，すべ てのデータを昭和 59 年価格に換算して, 駅からの 距離について $100 \cdot \mathrm{M}$ ピッチで平均化し, 地価データ とした。

(2) モデルの構造

モデルの構造としては, 都心を中心とした鉄道の 影響を受けない（駅勢圈外の）大すりばち型分布 （これを「基礎地価」と名づける。）と，駅勢圈内

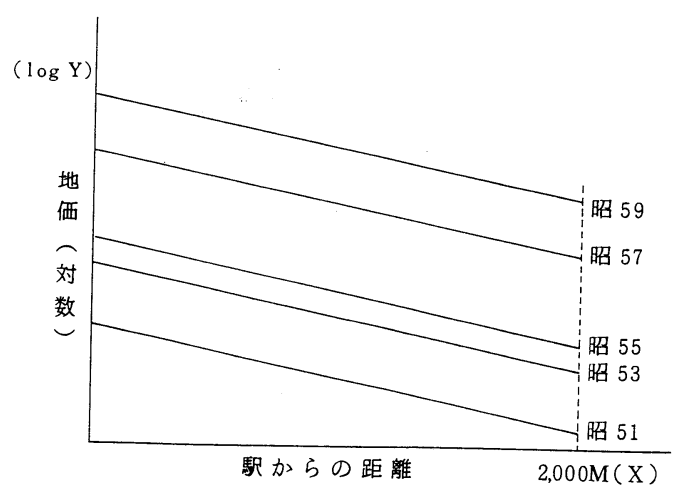

図 1 (1)式の回帰線

の小すりばち型地価分布を想定した。（図 2 参照） 各駅勢圏については, 駅無限遠方で一定值（＝C）

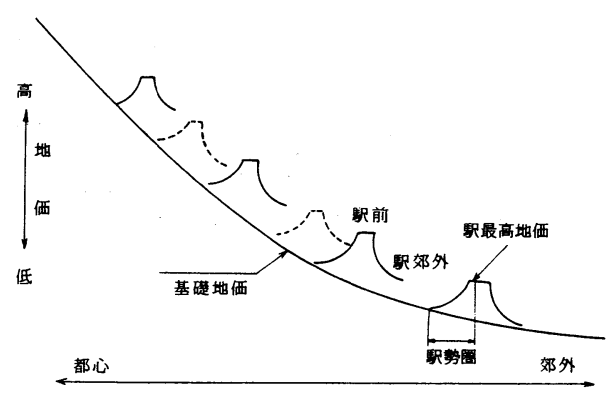

図 2 地価分布の想定

に収束するような以下の二種の非線形関数によって 回帰を行なった。(図 3 参照)

$$
\begin{aligned}
& \mathrm{Y}=\mathrm{A} * \mathrm{e} \times \mathbf{p}(-\mathrm{B} * \mathrm{X})+\mathrm{C} \quad \text { (指数型) (2) } \\
& \mathrm{Y}=-\mathrm{A} * \mathrm{X}+\mathrm{B} \quad \text { if } \mathrm{X} \leq \mathrm{X}_{0} \quad \text { （折線型） (3) } \\
& \mathrm{Y}=\mathrm{C} \quad \text { if } \mathrm{X}>\mathrm{X} \text { 。 } \\
& \text { (ただし } \left.\mathrm{X}_{0}=(\mathrm{B}-\mathrm{C}) / \mathrm{A}\right)
\end{aligned}
$$

なお，係数の推定にあたっては，マルカル法によ る非線形回㷌法を用いた。

指数型分布では, 駅からの距離が遠くなるにつれ 


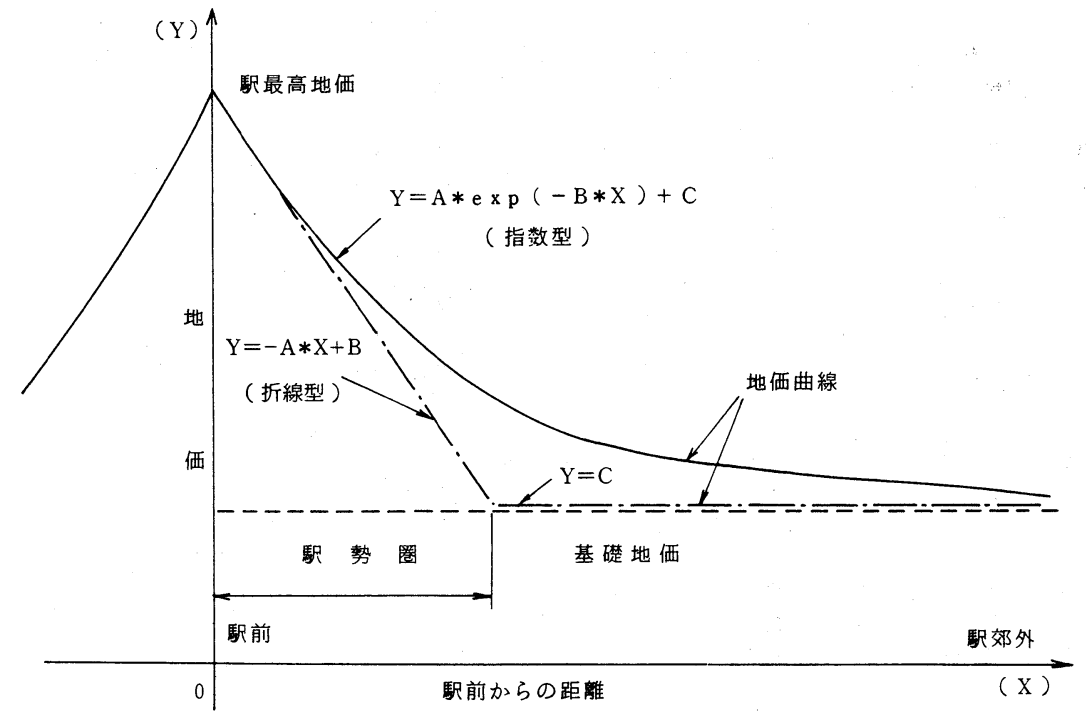

図 3 各駅勢圏における地価分布のモデリング
をその都市の地

価分布型とした。

（注 6 ）以上よ

り, 「指数型都

市」は,川口，

颜, 大宮, 久喜, 上尾, 熊谷, 川 越, 朝霞, 上福 岡, 東松山, 和 光の 11 都市, 一方, 「折線型 都市」は, 与野, 蓮田, 桶川, 北 本, 草加, 志木, 富士見, 所沢， 越谷, 飯能の 10 都市に分類され た。
て地価が漸减するが，折線型では，折れ点を有し， 駅勢圏が明確に表れる。

対象地域は, 首都圏のうち, アクセスする都心が 集中的であり, 複数の通勤鉄道が存在し, 図 2 の地 価分布を最も顕著に示す地域として, 埼玉県を選ん だ。対象駅は, 都心からの時間距離 (注 1 ) が 70 分以内の 37 駅とした。（注 2 ) (2)及び(3)式におい て収束值 Cを推定するためには, 駅からできる限り 遠方まで，データを含めるととが望ましいが，鉄道 の影響を受けない他市町村の影響が考えられるため， 駅から $5 \mathrm{~km}$ 圏のデータを, 式の推定のために採用し た。

(3) 推定結果と地価分布分類

回㷌を行ったのち, 適合度( = 1 - (残差自乗和 （全変動））（注 3 ）の良し要しにょり, 原則とし て,「指数型分布」，「折線型分布」に分類した。 (注 4 ) 結果は表 1 に示した。（注 5 ）「折線型分 布」の駅勢圏については, 駅勢圏が推定可能となる。 更に，駅が属する都市について，「指数型都市」， 「折線型都市」にグルーピングを行なった。同一市 に複数駅が存在する場合で, 該当駅が異なる地価分 布型を示した場合には, 原則として代表駅の分布型

\section{3. 駅勢圈内地価分布の特性}

このような異なった地価分布型をとる都市群につ いて, 「指数型」, 「折線型」両都市の性格差をさ ぐるために, 各都市の 12 の統計指標（注 7 ）に対 し, 分散分析を行ない, 群間差が有意 ( $10 \%$ 水準) となる 5 指標を得た。(表 2 参照)

この結果, 「指数型都市」は, 工業生産が盛んで 工業用地も広い。加えて, 昼夜率が高いことから, 自都市内で, ある程度以上の従業者を抱えることが 可能であり, 都市としての自立度が高いものと考え られる。これに反して，「折線型都市」については， 工業があまりみられず, 逆に住宅用地が多くなって いる。昼夜率が低いことを考えあわせれば，この都 市群は明らかに大都市依存のベッドタウン都市であ ることがわかる。更に, 興味深いのは, 置市経過月 数に関し，「指数型都市」の值が大きくなっている ことである。すなわち，「指数型都市」は比較的古 い街というわけであるが, 戦後の高度成長にともな った首都圈のスプロール化の結果, 生まれた都市を 「折線型都市」，それ以前からある程度街を形成 しており, 東京という大都市が仮になくとも自活で 
表 1 非線形回帰結果

\begin{tabular}{|c|c|c|c|c|c|c|c|c|c|}
\hline 駅名 & $\begin{array}{l}テ ゙-\text { 夕数 } \\
\text { (除外数) }\end{array}$ & $\begin{array}{l}\text { 逜合度 } \\
\text { 指数型 }\end{array}$ & 折線型 & 分類 & $\begin{array}{l}\text { 基硞地価 } \\
\text { (万円/平米) }\end{array}$ & $\begin{array}{l}\text { 駅最高地価 } \\
\text { (万円 /平米) }\end{array}$ & $\begin{array}{l}\text { 街最高地価 } \\
\text { (万円／平米) }\end{array}$ & $\begin{array}{c}\text { 駅勢圏 } \\
\text { (M) }\end{array}$ & $\begin{array}{l}\text { 街勢圈 } \\
(\mathrm{M})\end{array}$ \\
\hline 西川口 & $38(0)$ & .867 & .854 & 指数 & 13.15 & 28.32 & 21.65 & 2746 & 5319 \\
\hline 廐 & 33 (2) & .842 & .807 & 指数 & 16.03 & 29.84 & 20.69 & 1623 & 3172 \\
\hline 南浦和 & $18(0)$ & .897 & .894 & 不適 & 15.22 & - & - & - & - \\
\hline 浦和 & $27(0)$ & - & . 902 & 折線 & 11.36 & 28.50 & - & 3713 & - \\
\hline 北浦和 & $33(0)$ & . 942 & . 941 & 指数 & 11.11 & 29.11 & 16.81 & 3036 & 6394 \\
\hline 与野 & $19(0)$ & .823 & . 879 & 折線 & 14.43 & 24.44 & - & 2395 & - \\
\hline 大宫 & $26(0)$ & .905 & . 872 & 指数 & 9. 37 & - & 23.83 & - & 4178 \\
\hline 東大舁 & $18(0)$ & .895 & .881 & 指数 & 11.79 & 20.78 & 16.75 & 1097 & 1753 \\
\hline 蓮田 & $15(0)$ & - & . 848 & 折線 & 8. 33 & 15.26 & - & 2355 & - \\
\hline 久喜 & $19(1)$ & .886 & .875 & 指数 & 9.74 & 17.33 & 13.45 & 1211 & 2018 \\
\hline 宮原 & $16(2)$ & .768 & .721 & 不㗬 & 12.75 & - & - & - & - \\
\hline 上尾 & 29 (2) & .858 & .824 & 指数 & 7. 01 & 19.48 & 14. 99 & 2648 & 5309 \\
\hline 桶川 & 23 (1) & .907 & . 934 & 折線 & 10.26 & 15.75 & - & 1850 & - \\
\hline 北本 & $16(0)$ & .750 & .757 & 折線 & 9.60 & 16.92 & - & 1300 & - \\
\hline 熊谷 & 17 (1) & . 878 & . 833 & 指数 & 6. 43 & 20.77 & 12.70 & 1410 & 2632 \\
\hline 篒原 & 13 (1) & . 624 & . 696 & 折線 & 6. 55 & 9. 35 & - & 1300 & - \\
\hline 谷塚 & 18 (1) & .870 & . 918 & 折線 & 11.56 & 19.41 & - & 1948 & - \\
\hline 草加 & 27 (1) & . 698 & .746 & 折線 & 10.80 & 20.64 & - & 2033 & - \\
\hline 新田 & 21 (1) & .878 & .901 & 折線 & 12.35 & 18.90 & - & 1733 & - \\
\hline 越谷 & $12(0)$ & . 732 & . 788 & 折線 & 13.35 & 21.01 & - & 1875 & - \\
\hline 北越谷 & $15(5)$ & .887 & .881 & 指数 & 12.23 & 20.86 & 15.04 & 1255 & 2549 \\
\hline 和光市 & 11 (1) & .804 & .802 & 指数 & 17.14 & 27.86 & 20.38 & 1211 & 2206 \\
\hline 朝霞 & $20(0)$ & .788 & .761 & 指数 & 12.83 & 25.83 & 20.64 & 1633 & 3568 \\
\hline 志木 & 20 (1) & .796 & .807 & 折線 & 15.28 & 23.57 & - & 2551 & - \\
\hline 鶴瀬 & 19 (1) & .727 & .746 & 折線 & 13.10 & 19. 15 & - & 1700 & - \\
\hline 上福岡 & $23(0)$ & .870 & .854 & 指数 & 8. 54 & 22.95 & 18. 38 & 1945 & 4265 \\
\hline 川越 & 26 (1) & .865 & .817 & 指数 & 9. 01 & 24.52 & 17. 91 & 2631 & 5057 \\
\hline 坂戸 & 15 (1) & .857 & .771 & 不適 & 9.83 & - & - & - & - \\
\hline 東松山 & 14 (1) & .880 & .844 & 指数 & 7. 75 & 15.21 & 11.20 & 1443 & 2474 \\
\hline 所沢 & $18(0)$ & . 643 & . 652 & 折線 & 15.17 & 21.89 & - & 1700 & - \\
\hline 新所沢 & $15(0)$ & . 679 & .703 & 折線 & 16.81 & 22.46 & - & 1800 & - \\
\hline 饭能 & $13(2)$ & .778 & .793 & 折線 & 10.57 & 18.88 & - & 1769 & - \\
\hline
\end{tabular}

表 2 分散分析結果

\begin{tabular}{|c|c|c|c|c|c|}
\hline & $\begin{array}{l}\text { 一人当り } \\
\text { 工業生産 } \\
\text { 䫓 }\end{array}$ & $\begin{array}{l}\text { 工業用地 } \\
\text { 比率 }\end{array}$ & $\begin{array}{l}\text { 住宅用地 } \\
\text { 比率 }\end{array}$ & 昼致率 & $\begin{array}{l}\text { 置市経過 } \\
\text { 月数 }\end{array}$ \\
\hline F値 & 7. 26 & 3. 20 & 6. 17 & 4. 15 & 4. 13 \\
\hline 判定 & $\begin{array}{c}* * \\
(5 \%)\end{array}$ & $\begin{array}{c}* \\
(10 \%)\end{array}$ & $* *$ & $*$ & $*$ \\
\hline 「指数型」都市 & 大 & 大 & 小 & 大 & 大 \\
\hline 「折線型」都市 & 小 & 小 & 大 & 小 & 小 \\
\hline
\end{tabular}

きうる都市が「指数型都市」といえよう。
4.つけ值理論による駅勢圏内地価分布の解明

前節での実証分析により, 都市の自立性の有無に よって地価分布型が異なってくるととが示された。 都市の自立性は, 従業者を自都市内に抱えることが できるかどうかで定まってくるため, 通勤者に対し， 駅を利用する「都心通勤者」，及び, 駅を利用しな い「市内通勤者」の二種に分け, 地価形成の「つけ 值理論」に立脚しながら,「都心通勤者のつけ值」, 「市内通勤者のつけ值」を想定した。現実の地価分 布は, 両つけ値線の最大值を結ぶ線となる。

両通勤者の通勤条件の違いを考えてみると, 「都 心通勤者」は総通勤時間が相対的に長くなるうえ, 自家用車の使用が困難である。逆に，「市内通勤者」 の場合は, 従業地が C B D (一般的には駅前付近 ) を中心として拡散しているとと, 通勤時間に余裕 

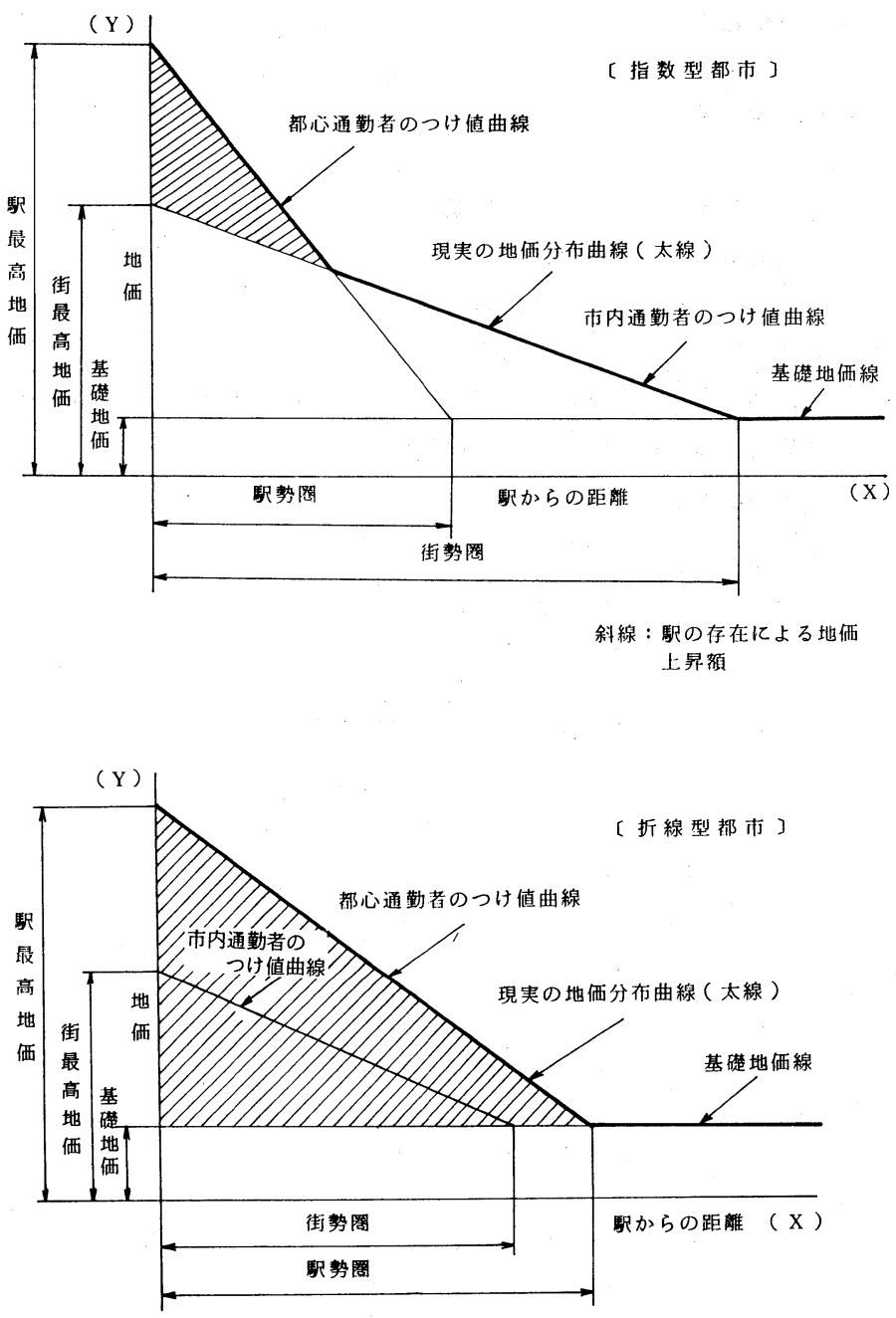

図 4 つけ値理論による都市の地価構造
少ないため,「市内通勤者のつ け值」は「都心通勤者のつけ值」 を下まわり，ての結果が，前 節で行なった非線形回帰におい て, 各々,「指数型」, 「折線 型」の関数系への適合度がすぐ れていたものと推察された。(図 4 ) てれによって,「指数型分 布」をとる駅においても，「都心 通勤者のつけ值線」を推定する ことにより, 駅勢圈が求められ るととがわかった。

このような通勤者特性の相違 から, 駅の存在による地価上昇 額（＝外部効果）を考える場合， 「指数型都市」では，その自 立性により, 駅の存在がなくと も, 「市内通勤者」は多数存在 し, 駅の存在による地価上昇額 は, 「都心通勤者のつけ值線」 と「市内通勤者のつけ值線」の 差の部分となる。（図 4 参照） ところが，「折線型都市」にお いては, 置市経過月数が短いて とから, 元来は街の形成がなか った地区であり，鉄道の存在に よって初めて街の形成がなされ るととから, 駅の存在がなかっ た場合には，「市内通勤者」も ほとんど存在しないと考えて良 い。したがって，「折線型都市」 については,「都心通勤者のつ
があるとと，自家用車の使用が可能であるととから， 駅遠方でも，比較的居住が可能であると考えられ る。

したがって，両つけ值線は交差し，駅近隣は「都 心通勤者のつけ值」，駅遠方では「市内通勤者のつ け值」によって地価が定まるととが考えられた。

この理論を各々の地価分布についてあてはめてみ ると, 都市の自立性が大きく，「市内通勤者」の多 い「指数型都市」では, 両つけ值線の交差がみられ るものの，「折線型都市」では，「市内通勤者」が
け值線」と「基礎地価」との差を駅の存在による地 価上昇額とした。（図 4 参照）

なお,「指数型都市」，「折線型都市」とも，実 際の地価上昇額は, 上述の差の部分を, 駅を中心に 一回転させた体積の部分に相等する。

\section{5. 駅勢圈内地価構造の特定}

以上のととから，両つけ值線によって，「指数型 都市」，「折線型都市」の地価構造が説明できるこ とがわかり，「指数型分布」の駅勢圏については, 
再び折線回帚を行なうととによって，両つけ値線を 推定した。

この結果を, 前節で行なった「折線型分布」の「都 心通勤者のつけ值線」の推定結果と合わせ, 二本 のつけ值線で構成される駅勢圏の地価構造を「基礎 地価」, 「駅最高地価」, 「駅勢圏」, 「街最高地 価」，「街勢圈」の五指標を定義するととによって 特定した。(図 4 参照) なお, 「折線型分布」の駅 においては, 「市内通勤者のつけ值線」を求めるこ とができないため, 二節で求めた「都心通勤者のつ け值線」の結果のみを用いる。よって, 「街勢圏」, 「街最高地価」は求まらない。結果は表 1 亿付記し た。

更に, 上記五指標を決定する要因を回帰分析によ って特定した。

（1）基礎地価（BLP）（万円／平米）

$\log (B L P)=2.846-0.01554 * X t$ (42. 4) (-7.52)

$+0.2851 * \mathrm{Ds}$

(3. 02$)$

$\left[\mathrm{R}^{2}=0.686 \quad \mathrm{~N}=32\right](\quad): \mathrm{t}$ 一值

$\mathrm{Xt}$ : 都心からの鉄道距離 $(\mathrm{km})$

Ds : 西武線ダミ一

（2）駅最高地価（SLP）（万円／平米）

$$
\begin{aligned}
\mathrm{SLP}= & 25.776-0.2296 * \mathrm{X}_{\mathrm{j}}+2.093 \\
& (13.91)(-6.36)
\end{aligned}
$$

* $\mathrm{K}+5.678 * \mathrm{Dk}$

(4. 64)

$\left[R^{2}=0.789 \quad N=28\right]$

$\mathrm{Xj}$ : 都心からの時間距離（分）

$\mathrm{K}$ ：駅の持つ系統数 (本)

$\mathrm{Dk}$ : 京浜東北線ダミー

(5)

\section{(3) 駅勢圏 ( S E ) ( M )}

「駅勢圈」の場合，28駅全体で回縞を行うと， 決定係数が十分でない。乙れは，私鉄駅の駅勢圈が 比較的小さく,また, 「都心からの時間距離」に対 しても, 国鉄駅に比べ, 変化が少るい傾向がある。 また, 「都心からの時間距離」が約 45 分を超え ると，国鉄駅，私鉄駅ともにほぼ一定值となる傾向 がみられた。そとで, 回䚻としては, 都心から一定 範冊の国鉄線（ただし，蔽駅と新駅である東大宮駅 はのぞいた久喜駅以近の 9 駅)で行なった。

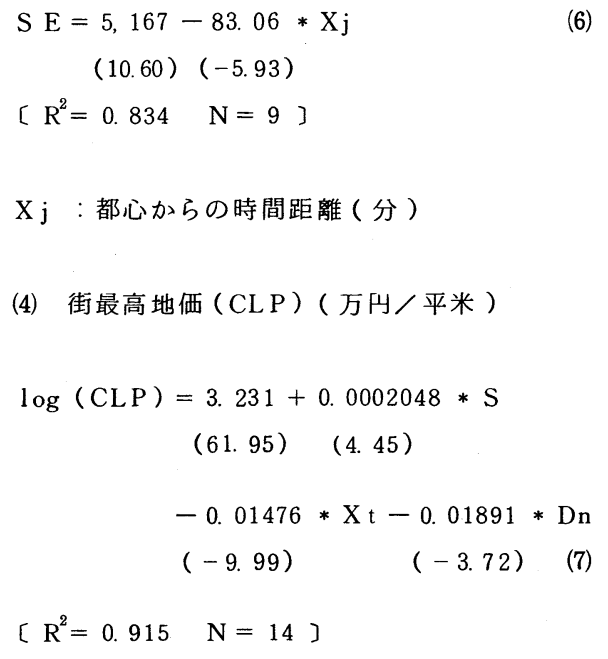

（4）街最高地価（CLP）（万H／平米）

$$
\begin{aligned}
& \log (\mathrm{CLP})=3.231+0.0002048 * \mathrm{~S} \\
& \text { (61. } 95) \quad(4.45) \\
& -0.01476 * \mathrm{Xt}-0.01891 * \mathrm{Dn}
\end{aligned}
$$

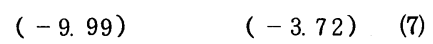

$$
\begin{aligned}
& {\left[\mathrm{R}^{2}=0.915 \quad \mathrm{~N}=14\right]}
\end{aligned}
$$

S : 駅所属市の商業販売額 (百万円 $/$ 年)

$\mathrm{Xt}$ : 都心からの鉄道距離 $(\mathrm{km})$

Dn : 駅所属市の非代表駅ダ

(5) 街勢圈（ C E )（ M ）

$\log (\mathrm{CE})=7.718+0.001393 * \mathrm{I}$

(49. 13) (3. 28)

$+0.5500 * \mathrm{Db}-0.9099 * \mathrm{Ds}$

(1. 74$) \quad(-2.97) \quad$ (8)

$\left[\mathrm{R}^{2}=0.626 \quad \mathrm{~N}=14\right]$

I : : 駅所属市の工業生産額 (百万円 $/$ 年 )

$\mathrm{Db}$ ：辺境駅ダ

Ds : 新駅ダミ一（東大宮駅） 
特に, 駅勢圏については, 従来の外部効果計則列 においては一定値として扱われるてとが多く，国鉄 駅に扔いては，より現実にあったモデリングとなっ た。また，「駅勢圏」の回㷌式は，「都心からの時 間距離」に対して, 負の回帰係数を有するととがわ かり，通勤時間余裕から考えた場合の，「都心から (該当駅までの) 時間距離」と「駅勢圈」との関係 を裏づける結果となった。

以上のことから，「都心通勤者のつけ值」で示さ れる, 駅の存在による地価は, 「都心からの時間距 離」によってかなりの部分を説明しうるととがわか り, 新線建設による地価上昇は, 㳱心からの時間距 離の改善という形で，本モデルによって定量化が可 能であるととが示された。

6. 埼京線建設を例とした沿線外部効果の定量化

前節で構築された地価構造モデルをもとに，埼京 線 (埼玉県内) の開通にともなう外部効果（＝地価 上昇総額）を算定した結果を表 3 に示す。上昇総額 は, 8,635 億円であるが, このうち, 公共用地比率 $25 \%$ (仮定), 住宅用地比率 $81.7 \%$ (浦和市, 昭 和 58 年) と想定すると, 住宅地に扔ける推定上昇 額は

8,635 億円 $\times(1-0.25) \times 0.817$

$$
=5,291 \div 5,300 \text { 億円 }
$$

となり, 平均地価上昇額は約 2.69 (万円/平米) と なった。ての上昇額は, 埼京線 (埼玉県内) の建設 費, 約 1,970 億円の約 2. 7 倍にあたる。したがって,

表 3 地価上昇額推定

\begin{tabular}{|c|c|c|c|}
\hline 駅名 & $\begin{array}{l}\text { 上界頡 } \\
\text { (嬑円) }\end{array}$ & $\begin{array}{l}\text { 上昇面穔 } \\
\text { (平方 } \mathrm{K} \mathrm{m} \text { ) }\end{array}$ & $\begin{array}{c}\text { 平均上昇额 } \\
\text { (万円／ } \\
\text { 平米) }\end{array}$ \\
\hline 戸田公囷 & 1478 & 4. 81 & 3.07 \\
\hline 戸田 & 1395 & 4. 81 & 2. 90 \\
\hline 北戸田 & 1322 & 4. 59 & 2. 88 \\
\hline 武蔵浦和 & 2695 & 7. 56 & 3.56 \\
\hline 中浦和 & 254 & 1. 48 & 1. 72 \\
\hline 南与纾 & $\begin{array}{lll}9 & 1 & 4\end{array}$ & 4. 70 & 1. 95 \\
\hline 与野本町 & 564 & 3. 79 & 1. 49 \\
\hline 北与野 & 12 & 0.32 & 0.38 \\
\hline
\end{tabular}

埼京線が埼玉県内沿線にもたらした地価上昇のうち， 約 $37 \%$ 何んらかの形で吸収, 内部化できれば, 埼京線建設費を回収するととが可能となるととがわ かった。このととは, 今後, 首都圏の通勤鉄道整備 を進めるうえで一つの目安となろう。

\section{7. 今後にむけて}

今回示した非線形地価関数は，まだ試作段階であ り, 今後様々な方向から精査していく必要があると 考えられる。特に検討しなければならないものとし て次の項目が考えられる。

（1）今回の研究は，埼玉県を対象とした分析であ ク，首都圈全体にも範囲を広げ，より一般性の ある, 地価分布と都市の性格との関係を調べて いく必要がある。

（2）地価に対して，「駅からの距離」以外にも影 響を与える要素は様々あるが, 非線形モデルの なかにどのように取り入れていくのかを考えて いかなければならない。

(3) 今回の分析では, 駅前まで住宅地が存在する ものとして, 地価上昇総額を算定したが，モデ ルをより現実的なものとするためには, 商業地 や工業用地などの地価形成を分析し，モデルの なかに取り入れていく必要があろう。

注 釈

注 1)「都心」の駅は山手線の駅とし, 「時間距 離」については, 普通料金で乗れる最短時間 （乗換時間ふくまず）とした。

注 2 ）都心への通勤範囲を明確にするため, 駅が 属する都市の，東京通勤者比率が，「都心一 の時間距離」を抵抗值としたグラビティモデ ルに追随しなくなる限界（都心から約 70 分 圏）をもって，首都通勤範囲とした。 
注 3 ）非線形回帰法では, 一般的な線形回帰の場 合と異なり, $\mathrm{t}$ 一值をはじめとする諸統計量 を用いるととができない吕したがって，モデ ルに用いた非線形関数は, パラメータ数が等 しいものを選び, 残差の自乗和の大小によっ て，モデルのフィッティングを評価した。

注 4 ) (1)収束值が,「指数型」，「折線型」ともに 負値となるなど，関数の回帰値が不自然な 場合には，「その他」の分類とし，除外と した。（鴻巣駅，春日部駅，狭山市駅）

(2)地価が駅を中心としたすりばち型分布を有 していない駅についても，同様に除外扱い とした。（加須駅，岩㶧駅）

(3)駅最近の地価データー点が著しく高い場合 には，「指数型」と判定されてしまうが, そのようなデータのある駅については, 「不 適」の分類とし, 基礎地価推定值以外の四 指標の值は用いなかった。なお，「基礎地 価」は, 「指数型」の回帰値を用いた。

(4)大宮駅については, 駅から $1 \mathrm{~km}$ 以近に地価 データがなく，「都心通勤者のつけ值線」 の推定誤差が大きくなる可能性があるため, 「駅勢圏」, 「駅最高地価」の値は不採用 とした。

注 5 ） データの除外にあたっては，次の基準によ った。

。残差の, 推定值に対する百分率が正規分布 をするという仮定のもとに，「指数型」， 「折線型」両関数ともに，有意水準 $5 \%$ で 裹却域におちる場合のデータは除外とした。

。上述の除去作業後も有意水準 $1 \%$ の棄却域 におちろ場合のデータも除外とした。

。「駅からの距離」において, $1 \mathrm{~km}$ 以上間隔 があき, 街が一旦途切れると判断される場 合の以遠のデータは除外とした。
注 6 ）該当するのは次の駅の場合である。

○. 浦和駅 (折線型), 北浦和駅 (指数型) 南浦和駅 ( 不適)

。熊谷駅 ( 指数型), 籠原駅 (折線型)

。越谷駅 (折線型), 北越谷駅 (指数型)

てのうち, 浦和市については三駅三様であ り，分散分析の対象外とした。熊谷市は「指 数型」, 越谷市は「折線型」の地価分布の分 類とした。

注 7 ) 具体的には, 次の指標である。

「一人当りの商業販売額」, 「一人当りの 工業生産額」，「一人当りの農業生産額」, 「昼夜率」, 「従業者に対する他都市からの 通勤者比率」, 「従業者に対する他都市への 通勤者比率」, 「商業用地比率」, 「工業用 地比率」，「住宅用地比率」，「市街化調整 区域比率」，「一人当りの市民所得」，「置 市経過月数」

$$
\text { 参考 文 献 }
$$

（1）肥田野, 中村, 太田「郊外鉄道新線建設効果 の資産価値への転移」土木計画学研究講演集 7

(2) 立地評価研究所「地価上昇の分配システム研 究」 1983

（3）運輸調査局「鉄道のもたらす外部経済効果の 研究」

（4）肥田野登、「新線開発の開発利益と吸収対策」 土木計画学シンポジウム 19

(5) 折下 功「鉄道新設による開発効果に関する 調査」 1970

(6) ドレーパー, スミス「応用回帰分析」森北 出版 1983 